\title{
Efficiacy of resveratrol and quercetin after experimental spinal cord injury
}

\author{
Ulvi Çiftçi, M.D., ${ }^{1}$ Emre Delen, M.D., ${ }^{2}$ Murat Vural, M.D., ${ }^{3}$ Onur Uysal, M.D., ${ }^{4}$ \\ Didem Turgut Coşan, M.D., ${ }^{5}$ Canan Baydemir, M.D., ${ }^{6}$ Fulya Doğaner, M.D. ${ }^{5}$
}

\author{
${ }^{1}$ Department of Neurosurgery, Bakırköy Dr. Sadi Konuk Training and Research Hospital, İstanbul-Turkey \\ ${ }^{2}$ Department of Neurosurgery, Trakya University Faculty of Medicine, Edirne-Turkey \\ ${ }^{3}$ Department of Neurosurgery, Eskişehir Osmangazi University Faculty of Medicine, Eskişehir-Turkey \\ ${ }^{4}$ Department of Histology, Eskişehir Osmangazi University Faculty of Medicine, Eskişehir-Turkey \\ ${ }^{5}$ Department of Medical Biology, Eskişehir Osmangazi University Faculty of Medicine, Eskişehir-Turkey \\ ${ }^{6}$ Department of Biostatistics, Kocaeli University Faculty of Medicine, Kocaeli-Turkey
}

\begin{abstract}
BACKGROUND: The aim of this study was to investigate the effect of natural antioxidants resveratrol and quercetin on oxidative stress and secondary cell damage in rats with acute spinal cord injury.

METHODS: In this experimental study, 42 male Sprague-Dawley rats were used. Spinal cord injury was performed with clip compression method at level of T4-5. The study was conducted using 6 groups: control, trauma, trauma and solvent, trauma and resveratrol, trauma and quercetin, and trauma with combined resveratrol and quercetin. All rats were euthanized 48 hours after the procedure. Effects of resveratrol and quercetin on serum and tissue total antioxidant capacity and paraoxanase activity level were examined.

RESULTS: Compared to trauma group, there was a significant increase in total antioxidant capacity and paraoxanase activity level in resveratrol, quercetin, and combined treatment groups. There was no significant difference between resveratrol and quercetin groups with regard to total antioxidant capacity and paraoxanase activity level. Total antioxidant capacity and paraoxanase activity level were significantly higher in solvent group than trauma group. In histopathological evaluation, there was a decrease in polymorphonuclear leukocyte infiltration in solvent, resveratrol, quercetin, and combined treatment groups.
\end{abstract}

CONCLUSION: Biochemical and histological staining results of present study showed that resveratrol and quercetin may be effective in preventing secondary damage in spinal cord injury.

Keywords: Antioxidant; experimental spinal cord injury; quercetin; resveratrol.

\section{INTRODUCTION}

Spinal cord injury $(\mathrm{SCl})$ is a clinical condition that often causes devastating outcomes such as permanent incapacity, especially in the younger population. It is well known that $\mathrm{SCl}$ is a type of trauma with no known effective therapeutic methods, and accordingly it is still difficult to estimate prog-

Address for correspondence: Ulvi Çiftçi, M.D.

Bakırköy Dr. Sadi Konuk Eğitim ve Araştırma Hastanesi,

Nöroşirürji Kliniği, İstanbul, Turkey

Tel: +90 212 - 414 7I7। E-mail: drulvi26@hotmail.com

Qucik Response Code Ulus Travma Acil Cerrahi Derg

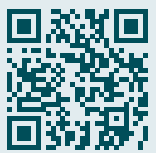

2016;22(5):423-43।

doi: $10.5505 /$ tjtes.20I6.44575

Copyright 2016

TJTES nosis. Poor prognosis and devastating outcomes of $\mathrm{SCl}$ justify scientific interest in the pathophysiology of $\mathrm{SCl}$ as well as in protective strategies and development of treatment options. ${ }^{[1,2]}$ Resveratrol and quercetin are naturally occurring antioxidative compounds that are referred to as polyphenols. Resveratrol reduces oxidation of low-density lipoprotein (LDL) by chelating copper (II) and phagocytizing oxygen free radicals. It also inhibits platelet aggregation and prevents thrombus formation and atherosclerosis, acting as a therapeutic agent to prevent potential cardiovascular disease..$^{[2-5]}$ Quercetin has a broad range of pharmacological characteristics such as anticancer, antiviral, antihistaminic, antitumoral, immunomodulatory, antioxidant, and anti-inflammatory properties. ${ }^{[5-10]}$ Recently, there have been studies conducted on antioxidant effects of these agents. The current study explored therapeutic effects and antioxidant properties of post-SCl administered resveratrol and quercetin on secondary cell damage. 


\section{MATERIALS AND METHODS}

Male Sprague-Dawley rats (weight: $250 \pm 50$ g; $n=42$ ) were supplied for the study by the experimental research center of Eskisehir Osmangazi University. Animals had 2-week period of adaptation to surroundings before initiation of study. They were housed in polycarbonate cages in a temperature- and humidity-controlled room $\left(21 \pm 10^{\circ} \mathrm{C}\right.$ and $45-55 \%$, respectively) with $12 / 12$ reversed light cycle. They were fed with standard rat chow and allowed to drink ad libitum. Procedures regarding animal care, surgery, and sample preparation were approved by the institutional animal care and experiments committee of Eskisehir Osmangazi University Faculty of Medicine. Regulations and guidelines for the care and use of laboratory animals of institutional animal care and experiments committee of Eskisehir Osmangazi University Faculty of Medicine (19.08.2009/130) were observed, as well as US National Institutes of Health guidelines regarding the care and use of animals for experimental procedures.

\section{Surgical Procedure}

The experimental $\mathrm{SCl}$ model was applied to 42 rats divided into 6 groups. Sedation was ensured with intramuscularly (i.m.) administered xylazine (Rompun; Bayer AG, Leverkusen, Germany) at dose of $10 \mathrm{mg} / \mathrm{kg}$, followed by ketamine hydrochloride (Ketalar; Pfizer, New York, NY, USA) i.m. at dose of $50 \mathrm{mg} / \mathrm{kg}$ for general anesthesia. Rivlin-Tator compression model (1978) was used: Surgical mark point was spinous process of $\mathrm{T} 2$ vertebrae, the most remarkable point of the rat spine. The area from T3 to T6 was shaved, and local surgery site antisepsis and environmental isolation were ensured. Midline skin incision was made through cutaneous and subcutaneous layers. Fascia was opened and paravertebral muscles were subperiostally lateralized. T4-T5 laminectomy was performed. Spinal cord was exposed and an aneurysm clip with extradural closing pressure of $50 \mathrm{~g}$ (Yaşargil clip FE 619K, Aesculap AG, Tuttlingen, Germany) was used to induce $\mathrm{SCl}$. In $\mathrm{SCl}$ groups, the clip was in place for I minute followed by immediate removal with clip holder. Post-SCl paraplegia was observed in all rats. Resveratrol and quercetin were dissolved in dimethyl sulfoxide (DMSO) and single dose I hour following $\mathrm{SCl}$ was administered. All rats were euthanized 48 hours after procedure. All procedures and group data are summarized in Table I.

\section{Biochemical Analyses}

Thoracic cavity of rats was opened under general anesthesia in order to determine total antioxidant status (TAS) level and paraoxonase-I (PON-I) activity. A blood sample of 3 $\mathrm{mL}$ was drawn from heart, centrifuged at $1000 \mathrm{rpm}$ for 10 minutes, and plasma was collected. Tissue samples and spinal cord samples of approximately $15 \mathrm{~mm}$ in length were taken from all groups and frozen in liquid nitrogen. Samples were transferred to tubes containing I $\mathrm{mL}$ IX phosphate buffer saline and processed in ultrasonic homogenizer. The resultant homogenate was centrifuged at $3500 \mathrm{rpm}$ for 15 minutes and supernatant was used for measurements. In plasma and tissue homogenates, TAS level was read using Shimadzu UV-I60I spectrophotometer (Shimadzu Corp., Kyoto, Japan) at absorbance level of $660 \mathrm{~nm}$ according to TAS assay kit (Rel Assay Diagnostics, Gaziantep, Turkey) procedures, while PON-I activity was measured using same device at absorbance level of $412 \mathrm{~nm}$ according to the PON-I kit (Rel Assay Diagnostics, Gaziantep, Turkey) procedures.

\section{Histological Examinations}

Approximately $15 \mathrm{~mm}$-long samples of spinal cord taken from control and experiment groups for histological evaluation included white matter, grey matter, and trauma site. All specimens were carefully excised and fixed in neutral buffered formalin for histological analyses. After fixation, tissue was embedded in paraffin and serial sections $(4 \mu \mathrm{m})$ were prepared for each paraffin block; on average, 50 sections were collected per rat. Sections were stained with hematoxylin and eosin for assessment of SCl. Digital images were obtained using Olympus BX-6I microscope (Olympus Corp., Tokyo, Japan) with a

Table I. Procedures performed and substances used according to experiment group

\begin{tabular}{|c|c|c|c|c|c|c|}
\hline \multirow[t]{2}{*}{ Group } & \multirow[t]{2}{*}{$\mathbf{n}$} & \multicolumn{2}{|c|}{ Procedure } & \multicolumn{3}{|c|}{ Substance } \\
\hline & & $\begin{array}{c}\mathrm{T} 4 \text { and } \mathrm{T5} \\
\text { laminectomy }\end{array}$ & $\begin{array}{l}\text { Spinal cord } \\
\text { injury }\end{array}$ & DMSO & $\begin{array}{c}\text { Resveratrol } \\
\text { (dissolved in DMSO) }\end{array}$ & $\begin{array}{c}\text { Quercetin } \\
\text { (dissolved in DMSO) }\end{array}$ \\
\hline C & 7 & $\sqrt{ }$ & - & - & - & - \\
\hline $\mathrm{SCl}$ & 7 & $\sqrt{ }$ & $\sqrt{ }$ & - & - & - \\
\hline SCl+DMSO & 7 & $\sqrt{ }$ & $\sqrt{ }$ & $0.3 \mathrm{~mL}$ i.p. & - & - \\
\hline $\mathrm{SCl}+\mathrm{R}$ & 7 & $\sqrt{ }$ & $\sqrt{ }$ & - & 100 mg/kg i.p. & - \\
\hline $\mathrm{SCl}+\mathrm{Q}$ & 7 & $\sqrt{ }$ & $\sqrt{ }$ & - & - & 200 mg/kg i.p. \\
\hline $\mathrm{SCl}+\mathrm{R}+\mathrm{Q}$ & 7 & $\sqrt{ }$ & $\sqrt{ }$ & - & 100 mg/kg i.p. & 200 mg/kg i.p. \\
\hline
\end{tabular}

C: Control group; DMSO: Dimethyl sulfoxide; i.p: Intraperitoneal; Q: Quercetin; R: Resveratrol; SCl: Spinal cord injury group; SCI+DMSO: Post-SCI DMSO group; $\mathrm{SCl}+\mathrm{Q}$ : Post-SCl quercetin group; $\mathrm{SCl}+\mathrm{R}$ : Post-SCl resveratrol group; $\mathrm{SCl}+\mathrm{R}+\mathrm{Q}$ : Post-SCl combined treatment group. 
DP70 digital camera. Histological scoring of SCl was as follows: no damage (0), very mild (I), mild (2), moderate (3), and severe (4). Tissue samples were also examined for hemorrhage, edema, necrosis, axonal swelling, chromatolysis, polymorphonuclear leukocyte (PMNL) infiltration and microglia/macrophage/MNL (mononuclear leukocytes) infiltration (Dobrowolski et al. 20 I I; Hausmann 2003; İş et al. 2006; Oyinbo 20 I I).

\section{Statistical Analyses}

Statistical analyses were performed using Statistical Package for the Social Sciences for Windows, version I I.0 (SPSS Inc., Chicago, IL, USA) and SigmaStat 3.5 (Statcon Inc., B. Schäfer, Witzenhausen, Germany) software packages. KolmogorovSmirnov normality test was used for data with normal distribution. Groups were compared using analysis of variance (ANOVA) for normally distributed data, and Tukey's HSD test for multiple comparisons; Kruskal-Wallis ANOVA test was used for non-normally distributed data. Results were expressed as mean \pm SD or median (25\%-75\% percentiles). A p value $<0.05$ was considered statistically significant.

\section{RESULTS}

\section{Biochemical Results}

Serum and tissue TAS and PON-I levels were lower in $\mathrm{SCl}$ group in comparison with the control group $(p<0.05)$. Although post-SCl resveratrol and quercetin increased serum and tissue TAS and PON-I levels in comparison with $\mathrm{SCl}$ group, there was no statistically significant difference between the 2 groups. The most remarkable increase was observed in post-SCl combined treatment group $(p<0.05)$ (Table 2$)$.

\section{Histological Results}

When spinal cord was examined with regard to hemorrhage, a remarkable difference was found in white and gray mat- ter of groups. When multiple comparison tests were examined in order to determine inter-group differences, significant increase was observed in hemorrhage in $\mathrm{SCl}$ and post-SCl DMSO groups compared with control group $(p<0.05)$ (Figs. Ia, c, d, 2a, b). It was observed that resveratrol administered in post-SCl period was more effective than quercetin in terms of eliminating hemorrhage (Figs. 2c, 3c).

Remarkable differences were also observed in white and gray matter of groups with regard to parameter of edema. Significant increase was observed in $\mathrm{SCl}$ and post-SCI DMSO groups in comparison with control group $(p<0.05)$. Particularly, a regression was observed in edema with post-SCI resveratrol and post-SCl combine treatment groups versus $\mathrm{SCl}$ group (Figs. 2c, 4c).

There were important differences in necrosis of white and gray matter, as well. Significant increase was observed in $\mathrm{SCl}$ and post-SCI DMSO groups compared with control group $(p<0.05)$ (Fig. Ib, 2b). It was observed that post-SCl resveratrol was effective achieving in regression of necrosis (Fig. 2d, 3a).

With regard to PMNL infiltration, there were important inter-group differences in white matter. Significant increase was observed in PMNL infiltration in $\mathrm{SCl}$ group in comparison with control group $(p<0.05)$ (Fig. Id). There was significant decrease in post-SCl combined treatment group in comparison with $\mathrm{SCl}$ group, and regression was observed in white matter of all groups $(p<0.05)$. There was significant difference between groups with regard to PMNL infiltration to the vessel wall and subarachnoid space. A significant increase was observed in PMNL infiltration to the vessel wall in the $\mathrm{SCl}$ group in comparison with control group $(p<0.05)$. There was a significant decrease in $\mathrm{PMNL}$ infiltration in post- $\mathrm{SCl}$ resve-

Table 2. Serum and tissue TAS and PON-I values of all groups (mean \pm SD or median $25 \%-75 \%$ percentiles)

\begin{tabular}{|c|c|c|c|c|}
\hline & $\begin{array}{c}\text { Serum TAS Level } \\
\text { (mmoL Trolox Eq/L) }\end{array}$ & $\begin{array}{c}\text { Tissue TAS Level } \\
\text { (mmoL Trolox Eq/L) }\end{array}$ & $\begin{array}{c}\text { Serum PON-I Level } \\
\text { (U/L) }\end{array}$ & $\begin{array}{c}\text { Tissue PON-I Level } \\
\text { (U/L) }\end{array}$ \\
\hline & Median $(25 \%-75 \%$ per.) & Mean $\pm S D$ & Mean \pm SD & Median $(25 \%-75 \%$ per.) \\
\hline C & $1.65(1.62-1.66)$ & $0.75 \pm 0.007$ & $|46.28 \pm 2.6|$ & 82.91 (80.06-84.37) \\
\hline $\mathrm{SCl}$ & $0.63(0.62-0.64)$ & $0.15 \pm 0.02$ & $67.11 \pm 2.89$ & $35.75(34.46-39.61)$ \\
\hline SCl+DMSO & $0.89(0.89-0.96)$ & $0.29 \pm 0.01$ & $81.18 \pm 4.05$ & $43.98(40.24-48.50)$ \\
\hline $\mathrm{SCl}+\mathrm{R}$ & $1.24(1.23-1.27)$ & $0.44 \pm 0.03$ & $104.71 \pm 1.81$ & $61.58(53.95-62.64)$ \\
\hline $\mathrm{SCl}+\mathrm{Q}$ & $1.23(1.10-1.24)$ & $0.42 \pm 0.03$ & $100.93 \pm 2.14$ & $58.75(52.95-60.74)$ \\
\hline $\mathrm{SCl}+\mathrm{R}+\mathrm{Q}$ & $1.39(1.36-1.46)$ & $0.61 \pm 0.02$ & $118.41 \pm 1.69$ & 70.01 (66.05-7I.35) \\
\hline Statistics & $\mathrm{H}=38.916^{\mathrm{a}}$ & $\mathrm{F}=655.156^{\mathrm{a}}$ & $\mathrm{F}=772.748^{\mathrm{a}}$ & $\mathrm{H}=38.380^{\mathrm{a}}$ \\
\hline Statistics, $\mathrm{p}$ & $<0.001$ & $<0.001$ & $<0.001$ & $<0.001$ \\
\hline
\end{tabular}

a: All groups different from each other $(\mathrm{p}<0.05)$ except SCI+R and SCl+Q (p>0.05); C: Control group; DMSO: Dimethyl sulfoxide; i.p: Intraperitoneal; PON-I: Paraoxonase-I; Q: Quercetin; R: Resveratrol; SCl: Spinal cord injury group; SCI+DMSO: Post-SCI DMSO group; SCl+Q: Post-SCl quercetin group; SCl+R: Post-SCI resveratrol group; $\mathrm{SCl}+\mathrm{R}+\mathrm{Q}$ : Post-SCl combined treatment group; TAS: Total antioxidant status. 
ratrol, quercetin and combined treatment groups compared with $\mathrm{SCl}$ group $(\mathrm{p}<0.05)$.

When microglia/macrophage/MNL infiltration was examined, important differences were observed in white and gray matter. Microglia/macrophage/MNL infiltration was not observed in white matter of control and $\mathrm{SCl}$ groups or post-SCl resveratrol group. Significant increase in microglia/macrophage/ MNL infiltration was observed in white and gray matter of quercetin and combined treatment groups in comparison with $\mathrm{SCl}$ group $(p<0.05)$ (Fig. 3b, 4c). Therefore, it was determined that quercetin was more effective than resveratrol against increased microglia/macrophage/MNL infiltration.

It was found that resveratrol and quercetin had no beneficial effect on axonal swelling induced with $\mathrm{SCl}$.

It was also determined that chromatolysis had non-significant
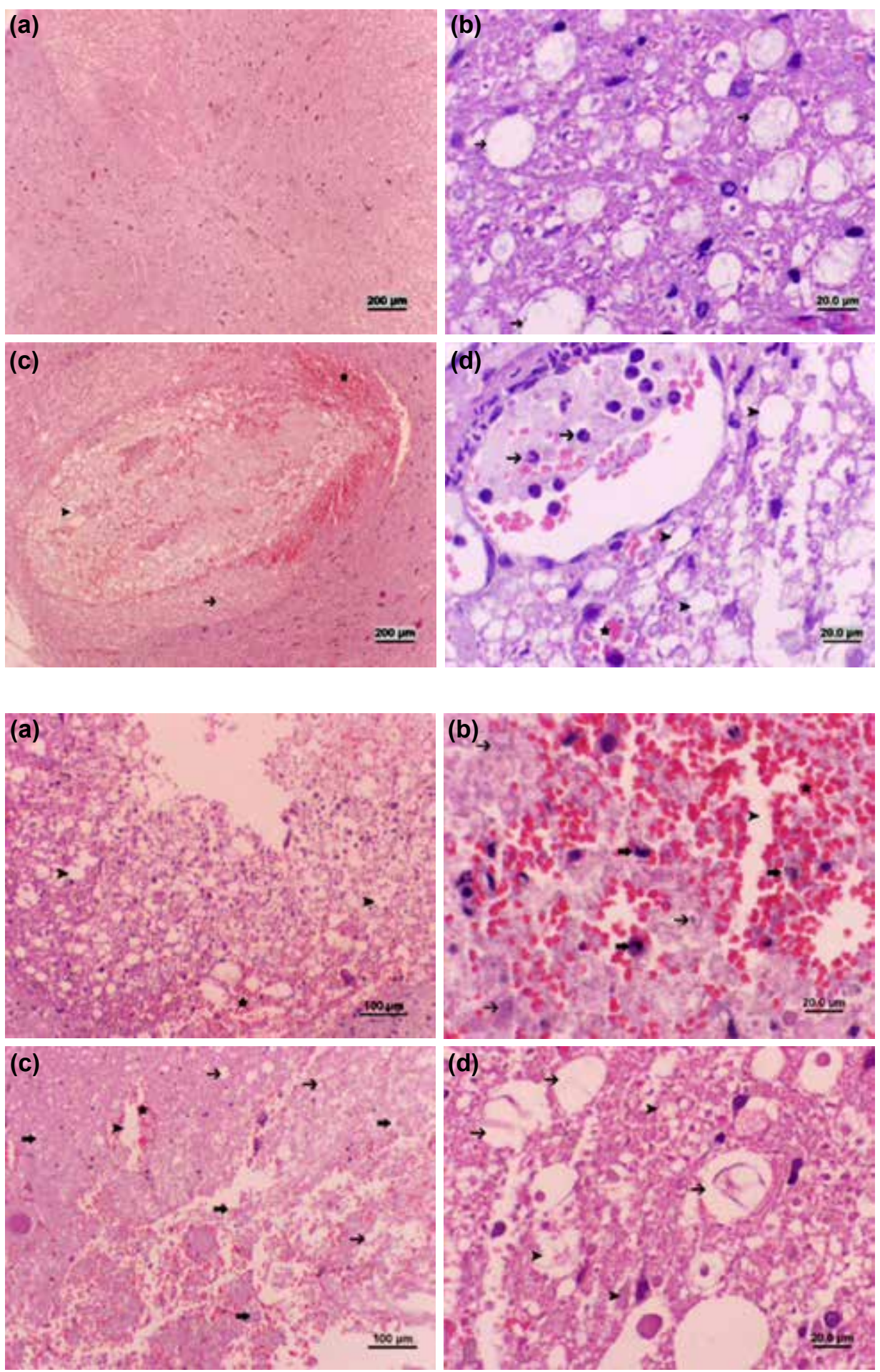

Figure 1. Spinal cord tissue morphology indicated by hematoxylineosin staining in control and $\mathrm{SCl}$ groups. (a)Control group; normal view. H\&E, Scale Bar $200 \mu \mathrm{m}$. (b) $\mathrm{SCl}$ group; moderate axonal swelling (arrow) and necrosis in the white matter. H\&E, Scale Bar $20 \mu \mathrm{m}$. (c) $\mathrm{SCl}$ group; severe axonal swelling (arrow), hemorrhage (asterisk), edema (arrow head) and necrosis in the white matter. H\&E, Scale Bar 200 $\mu \mathrm{m}$. (d) SCl group; moderate PMNL infiltration (arrow) in vascular wall, severe axonal swelling (arrow head), hemorrhage (asterisk), edema and necrosis in the white matter. H\&E, Scale Bar $20 \mu \mathrm{m}$.

Figure 2. Spinal cord tissue morphology indicated by hematoxylin-eosin staining in post-SCI DMSO and postSCI Resveratrol groups. (a) Post-SCI DMSO group; moderate hemorrhage (asterisk), edema, axonal swelling (arrow head), and severe necrosis in the white matter. H\&E, Scale Bar 100 $\mu \mathrm{m}$. (b) Post-SCI DMSO group; mild microglia/macrophage/MNL infiltration (thick arrow) and severe hemorrhage (asterisk), edema (arrow head) and necrosis (thin arrow) in the white matter. H\&E, Scale Bar $20 \mu \mathrm{m}$. (c) Post-SCl Resveratrol group; severe hemorrhage (asterisk), edema (arrow head), necrosis, axonal swelling (thin arrow) and chromatolysis (thick arrow) in the White and gray matter. H\&E, Scale Bar $100 \mu \mathrm{m}$. (d) Post-SCl Resveratrol group; severe axonal swelling (arrow) and necrosis (arrow head) in the white matter. $\mathrm{H} \& \mathrm{E}$, Scale Bar $20 \mu \mathrm{m}$. 

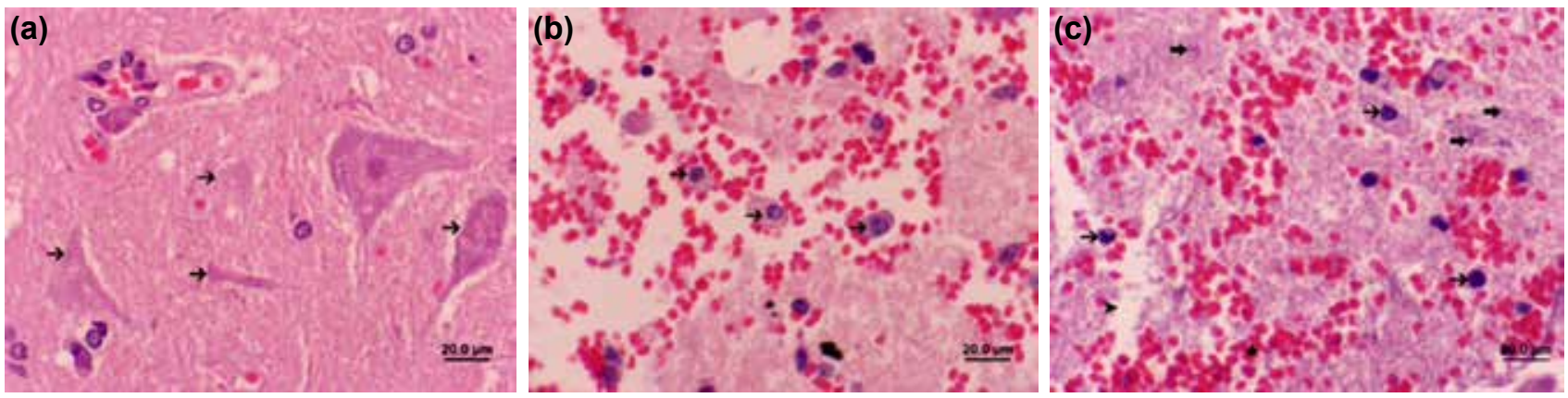

Figure 3. Spinal cord tissue morphology indicated by hematoxylin-eosin staining in post-SCI Quercetin group. (a) Post-SCl Quercetin group; mild chromatolysis (arrow) and necrosis in the gray matter. H\&E, Scale Bar $20 \mu \mathrm{m}$. (b) Post-SCI Quercetin group; severe microglia/ macrophage/MNL infiltration (arrow) in the white matter. H\&E, Scale Bar $20 \mu \mathrm{m}$. (c) Post-SCl Quercetin group; severe hemorrhage (asterisk), edema (arrow head), necrosis (thick arrow) and mild microglia/macrophage/MNL infiltration (thin arrow) in the white matter. H\&E, Scale Bar $20 \mu \mathrm{m}$.
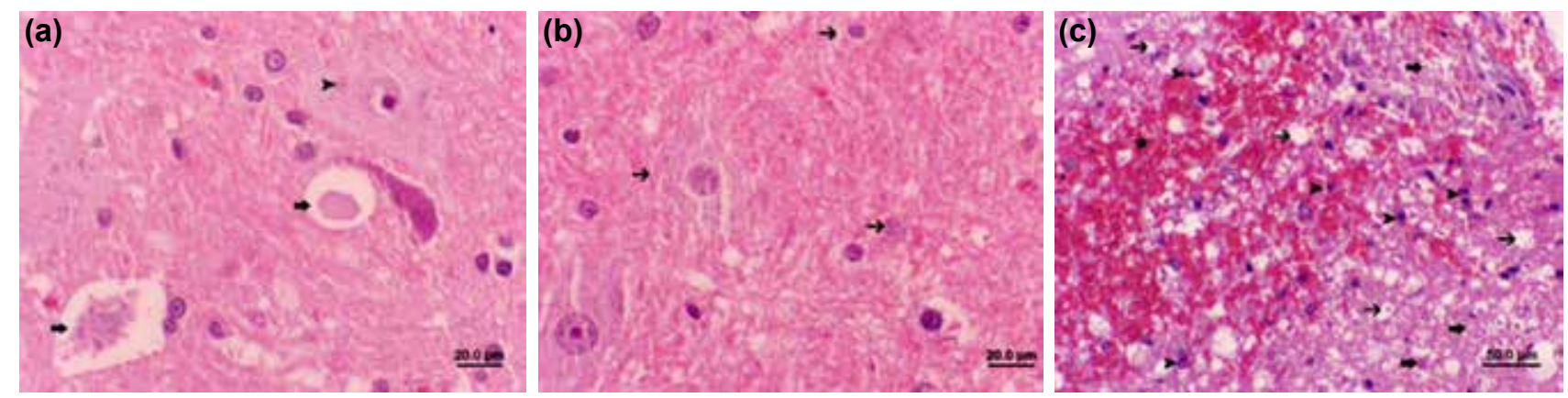

Figure 4. Spinal cord tissue morphology indicated by hematoxylin-eosin staining in Post-SCl combined treatment group. (a) Post-SCl combined treatment group; mild chromatolysis (arrow) and necrosis (arrow head) in the gray matter. H\&E, Scale Bar $20 \mu \mathrm{m}$. (b) Post-SCl combined treatment group; severe chromatolysis (arrow) in the gray matter. H\&E, Scale Bar $20 \mu m$. (c) Post-SCl combined treatment group; moderate hemorrhage (asterisk), edema, necrosis (thick arrow), axonal swelling (thin arrows) and microglia/macrophage/MNL infiltration (arrow head) in the white matter. H\&E, Scale Bar $50 \mu \mathrm{m}$.

decrease trend in post-SCl combined treatment group in comparison with $\mathrm{SCl}$ group (Fig. 4a, b).

Considering all available histological findings, the notable common finding was that PMNL infiltration, an indicator of primary response, had statistically significant decrease in post-SCl resveratrol, quercetin, and combined treatment groups $(\mathrm{p}<0.05)$, and it had tendency to completely disappear. It was observed that indicator of secondary response, microglia/macrophage/MNL infiltration, significantly increased in post-SCl quercetin and combined treatment groups $(p<0.05)$. When all available results were examined, it was seen that resveratrol is more efficient in primary response and quercetin is more efficient in secondary response, and most effective result was obtained in post-SCl combined treatment group (Table 3).

\section{DISCUSSION}

Resveratrol produces anti-inflammatory and anti-anaphylactic effects by influencing arachidonic acid metabolism. It possesses antibacterial, anti-cancerous and anti-mutation effects, and inhibits protein kinase activity. All those properties indicate that resveratrol could affect pathophysiological processes of inflammatory or traumatic reactions..$^{[2,3,5]}$
Yang and Piao demonstrated that resveratrol and methylprednisolone (MP) had protective effect against secondary damage that occurred following $\mathrm{SCl} .{ }^{[2]}$ Moreover, they determined that resveratrol had effect on post-SCl energy metabolism, inhibition of lipid peroxidation was more effective, and resveratrol had potent therapeutic effect on $\mathrm{SCl}$. Recent investigations indicate that resveratrol is potential antioxidant, since it prevents formation of free radicals in tissue such as red cell membrane, heart, liver, brain, and kidney; prevents functional injury and improves nerve function; and promotes restoration after trauma. Resveratrol is a candidate as therapeutic agent to ameliorate neurodegenerative processes. Kızltepe et al. demonstrated that resveratrol protects spinal cord against ischemia-reperfusion damage by reducing oxidative stress and increasing free nitric oxide (NO). ${ }^{\left[{ }^{\prime \prime}\right]}$ In s study conducted by Cemil et al., post-SCl effects of curcumin and MP were compared in biochemical and histopathological terms. [12] Curcumin, another polyphenol, has antioxidative, anticancerous, and anti-inflammatory effects. In curcumin group, tissue malondialdehyde (MDA) level decreased and levels of antioxidant enzymes copper-zinc superoxide dismutase, catalase, and phospholipid hydroperoxide glutathione peroxidase increased. Moreover, it was demonstrated that curcumin histopathologically protected tissue integrity. In rats with in- 
Table 3. Histological analysis results of all groups (median $25 \%-75 \%$ percentiles)

\begin{tabular}{|c|c|c|c|c|c|c|c|c|}
\hline & & CG & SCl & SCl+DMSO & $\mathbf{S C l}+\mathrm{R}$ & $\mathrm{SCl}+\mathrm{Q}$ & $\mathbf{S C l}+\mathbf{R}+\mathbf{Q}$ & Analysıs (p) \\
\hline \multirow[t]{2}{*}{ Hemorrhage } & WM & $0(0-0)$ & $4(2.25-4)$ & $3(2.25-3.75)$ & $2(2-2.50)$ & $3.50(3-4)$ & $3(2-3)$ & $24.906(<0.00 \mathrm{I})^{\mathrm{a}, \mathrm{a}, \mathrm{d}}$ \\
\hline & GM & $0(0-0)$ & $3(1.25-4)$ & $3(2-3)$ & $0(0-0.50)$ & $2(1-4)$ & $1.50(0-2)$ & $23.722(<0.00 \mathrm{I})^{\mathrm{a}, \mathrm{b}, \mathrm{d}}$ \\
\hline \multirow[t]{2}{*}{ Edema } & WM & $0(0-0)$ & $4(2.50-4)$ & $3(3-4)$ & $3(3-4)$ & $4(4-4)$ & $3.50(2-4)$ & $24.405(<0.00 \mathrm{I})^{\mathrm{a}, \mathrm{b}, \mathrm{d}}$ \\
\hline & GM & $0(0-0)$ & $4(1.25-4)$ & $2(2-2.75)$ & $2(I-2)$ & $2.50(2-3)$ & $2(I-2)$ & $22.033(<0.00 \mathrm{I})^{\mathrm{a}, \mathrm{b}, \mathrm{d}}$ \\
\hline \multirow[t]{2}{*}{ Necrosis } & WM & $0(0-0)$ & $4(3.25-4)$ & $4(3-4)$ & $2(2-3)$ & $4(3-4)$ & $3(2-3.50)$ & $27.532(<0.00 \mathrm{I})^{\mathrm{a}, \mathrm{b}, \mathrm{d}}$ \\
\hline & GM & $0(0-0)$ & $3(2.25-3)$ & $3(3-3)$ & $2.50(2-3)$ & $3(3-4)$ & $2(2-3)$ & $24.518(<0.00 I)^{a, b, d}$ \\
\hline \multirow[t]{4}{*}{ PMNL infiltration } & WM & $0(0-0)$ & $3(2-4)$ & $0(0-0)$ & $0.50(0-1)$ & I (0-2) & $0(0-0.50)$ & $28.83 \mathrm{I}(<0.00 \mathrm{I})^{\mathrm{a}, \mathrm{f}, \mathrm{h}}$ \\
\hline & GM & $0(0-0)$ & $2(0-2)$ & $0(0-0)$ & $0(0-0)$ & $0(0-0)$ & $0(0-0)$ & |6.67| (>0.05) \\
\hline & WW & $0(0-0)$ & $3(3-4)$ & $2(0-4)$ & $0(0-0.50)$ & $0(0-0)$ & $0(0-0)$ & $26.928(<0.00 \mathrm{I})^{\mathrm{a}, \mathrm{g}, \mathrm{h}}$ \\
\hline & SAS & $0(0-0)$ & $3(3-4)$ & $3(0-4)$ & $0(0-0.50)$ & $0(0-1)$ & $0(0-0)$ & $21.086(<0.00 \mathrm{I})^{\mathrm{a}, \mathrm{h}}$ \\
\hline Microglia/macrophage/MNL & WM & $0(0-0)$ & $0(0-0)$ & $2(2-2.75)$ & I (I-2) & $3(3-4)$ & $3(3-3)$ & $39.506(<0.00 \mathrm{I})^{\mathrm{d}, \mathrm{I}}$ \\
\hline Infiltration & GM & $0(0-0)$ & $0(0-0)$ & $2(2-2)$ & $0(0-1.50)$ & $2(2-4)$ & $3(2-3)$ & $37.203(<0.00 \mathrm{I})^{\mathrm{d}, \mathrm{e}, \mathrm{g}, \mathrm{k}, \mathrm{I}}$ \\
\hline Axonal swelling & & $0(0-0)$ & $4(2.50-4)$ & $3(2.25-4)$ & $3(3-4)$ & $4(3-4)$ & $3(2.50-4)$ & $22.100(<0.00 \mathrm{I})^{\mathrm{a}, \mathrm{c}, \mathrm{d}}$ \\
\hline Chromatolysis & & $0(0-0)$ & $3(2-3)$ & $3(3-4)$ & $3(3-3)$ & $3.50(3-4)$ & $2(1.50-3)$ & $27.109(<0.00 \mathrm{I})^{\mathrm{b}, \mathrm{c}, \mathrm{d}}$ \\
\hline
\end{tabular}

0: No damage; I: Very mild; 2: Mild; 3: Moderate; 4: Severe.

a: $\mathrm{p}<0.05$ for control group and SCl group; b: $\mathrm{p}<0.05$ for control group and SCl+DMSO group; c: $\mathrm{p}<0.05$ for control group and SCl+R group; CG: Control group; $\mathrm{D}$ : $\mathrm{P}<0.05$ for control group and $\mathrm{SCl}+\mathrm{Q}$ group; DMSO: Dimethyl sulfoxide; $\mathrm{E}: \mathrm{p}<0.05$ for control group and $\mathrm{SCl}+\mathrm{R}+\mathrm{Q}$ group; $\mathrm{F}$ : $\mathrm{p}<0.05$ for $\mathrm{SCl}$ group and $\mathrm{SCl}+\mathrm{DMSO}$ group; G: $\mathrm{p}<0.05$ for SCl group and $\mathrm{SCl}+\mathrm{Q}$ group; GM: Gray matter; $\mathrm{H}: \mathrm{p}<0.05$ for SCl group and $\mathrm{SCl}+\mathrm{R}+\mathrm{Q}$ group; $\mathrm{K}$ : $\mathrm{p}<0.05$ for $\mathrm{SCl}+\mathrm{R}$ group and SCl+Q group; L: $\mathrm{p}<0.05$ for SCl+R group; MNL: Mononuclear leukocytes; PMNL: Polymorphonuclear leukocyte; Q: Quercetin; R: Resveratrol; SAS: Subarachnoid space; SCI: Spinal cord injury group; SCI+DMSO: Post-SCI DMSO group; $\mathrm{SCl}+\mathrm{Q}$ : Post-SCl quercetin group; $\mathrm{SCl}+\mathrm{R}$ : Post-SCl resveratrol group; $\mathrm{SCl}+\mathrm{R}+\mathrm{Q}$ : Post-SCl combined treatment group; $\mathrm{VW}$ : Vessel wall; WM: White matter.

duced $\mathrm{SCl}$, it was found that curcumin was as biochemically and histopathologically effective as MP in functional improvement. Ates et al. investigated the effects of resveratrol and $\mathrm{MP}$ on induced $\mathrm{SCl}$ and found that MDA, NO and xanthine oxidase levels were lower and glutathione groups were higher in resveratrol and resveratrol+MP (combination) groups in comparison with just MP group. ${ }^{[13]}$ It was observed that neurological improvement was better in resveratrol and combined treatment group relative to MP alone group. No significant histological difference was found in the treated groups. It was found in the current study that resveratrol was as effective as MP on secondary damage that occurs in post-SCl period and combined treatment offered no extra protection in chronic phase of $\mathrm{SCl}$. It was determined that resveratrol and quercetin combination ameliorated post-traumatic oxidative stress and led to regression of edema. Therapeutic value and mechanisms of resveratrol on $\mathrm{SCl}$ should be studied further.

One means of antioxidant action exerted by quercetin involves scavenging free radicals, such as superoxide radicals generated by xanthine and xanthine oxidase. The antioxidant capacity of this molecule may be a very significant function and responsible for many of the beneficial effects. Quercetin interferes with the production of reactive oxygen species and reduces tissue damage through chelating effect and elimination of lipid peroxidation. ${ }^{[5-7,10]}$

It has been reported that quercetin is effective in prevention of oxidative damage to DNA or to cell membrane. One possible mechanism is that quercetin stabilizes lipid membranes and protects lipid peroxidation by exerting free radical scavenging effects. Quercetin is characterized by strong oxygen radical scavenging property and good metal chelating. Quercetin diffuses into membranes at high concentrations, resulting in antioxidative effect, and thus, it may scavenge oxyradicals at several sites through lipid bilayer. Pentahydroxyflavone structure possibly allows it to chelate metal ions via orthodihydroxy phenolic structure and thereby scavenge lipid alkoxyl and peroxyl radicals. It has also been suggested that quercetin acts as an antioxidant by inhibiting oxidative enzymes such as xanthine oxidase, lipoxygenase, and nicotinamide adenine dinucleotide phosphate oxidase. Inhibition of these enzymes is also responsible for attenuation of oxidative stress, as they play key role in initial process of free radical-induced cellular damage. Further, it has been reported that quercetin metabolites can also inhibit peroxynitrite-mediated oxidation, similar to free quercetin. In addition to direct hydrogen-donating properties, attention has focused on influence of quercetin on signaling pathways and its indirect interaction with endogenous antioxidant defense system. ${ }^{[5,10]}$

Epidemiological studies have indicated beneficial effects of quercetin in neural protection. ${ }^{[14]}$ Cerebral neuroprotective effect of quercetin derives from anti-oxidative effect and free radical scavenging property. ${ }^{[15,16]}$ In a study conducted by Genovese et al., the authors investigated effect of Hyperi- 
cum perforatum extract on neuroprotection and neuronal improvement in rats after $\mathrm{SCl}$ was induced. ${ }^{\left[{ }^{[1]}\right]}$ Hypericum perforatum extract comes from an herb that is a member of polyphenol group and contains flavonoid and phenolic acid. It was determined that Hypericum perforatum extract improved spinal cord inflammation, tissue damage, and PMNL infiltration. It was also found to improve neuronal function. In an experimental study conducted by Schültke et al. (20I0), it was demonstrated that the extract protected tissue integrity in the area of $\mathrm{SCl}$ and success rate of the treatment was dependent on frequency of administration and total dose. ${ }^{[18]}$ Schültke et al. (2003) demonstrated in other experimental study that amelioration of secondary damage via chelation of iron is an important mechanism in functional improvement after $\mathrm{SCl}$ develops that is supported by quercetin. ${ }^{[19]}$

Although primary physiological role of PON-I is not still completely known, recent studies have demonstrated that it is associated with high-density lipoprotein (HDL) cholesterol and prevents lipid peroxidation by playing protective role against oxidative modification of LDL cholesterol in addition to having antioxidant and anti-inflammatory activities. ${ }^{[20-22]}$ In patients with diseases characterized by increased oxidative damage, the higher tendency of HDL for peroxidation is considered to be related to decreased PON-I activity. ${ }^{[23]}$ It has been observed that PON-I offers protection against lipid peroxidation damage caused by free radicals on cell membranes and lipoproteins. ${ }^{[24]}$

In a study conducted by Rael et al., plasma oxidation reduction potential, PON-I and arylesterase activity were measured in 39 patients with multiple traumas and results were compared with those of 10 healthy volunteers. ${ }^{[25]}$ It was determined that PON-I and AE activity were significantly lower in patients with multiple traumas, and those parameters may be beneficial when severity of trauma and potential efficiency of treatment are examined. In the current study, significantly higher serum and tissue TAS and PON-I activity levels found in post- $\mathrm{SCl}$ resveratrol group relative to $\mathrm{SCl}$ and post- $\mathrm{SCl}$ DMSO groups are consistent with findings of Ates et al (2006; 2007) indicating increased glutathione peroxidase level in rats given resveratrol after $\mathrm{SCl}$ and head trauma. ${ }^{[13,25]}$ Elmali et al. demonstrated that resveratrol significantly reduced MDA level in ischemia/reperfusion damage of skeletal muscle. ${ }^{[26]}$ It was also observed in the current study that TAS level, which indicates total antioxidative effect, increased in resveratrol treatment group. It can be speculated that effect derives from anti-oxidative effect and free radical scavenging property of resveratrol as determined in the literature, particularly studies conducted by Ates et al. (2006; 2007). ${ }^{[13,26]}$ The increased level of TAS indicates that resveratrol offers better protection against oxidative damage of the spinal cord. In addition, in the current study it was seen that PON-I activity increased in rats given resveratrol. As indicated in studies conducted by Elmali et al. and Ray et al., resveratrol may inhibit lipid peroxidation and alleviate $L D L$ oxidation by binding free radicals.
${ }^{[27,28]}$ We observed in the current study that serum and tissue TAS levels and PON-I activities were significantly higher in quercetin group relative to $\mathrm{SCl}$ and $\mathrm{SCl}+\mathrm{DMSO}$ groups. Increase may be due to antioxidative effects deriving from free radical scavenging properties.

In the present study it was found that serum and tissue TAS levels and PON-I activities in DMSO group were significantly higher than $\mathrm{SCl}$ group and lower than control group. DMSO, which was used as solvent, is a free oxygen radical scavenger, largely specific to hydroxyl radicals. Turan et al. demonstrated substantial neuroprotective effect of DMSO in rabbits with induced spinal cord ischemia/reperfusion damage. ${ }^{[29]}$ In a study conducted by Chiueh et al., it was also demonstrated that DMSO suppressed generation of free radicals in cranial trauma. ${ }^{[30]}$ In the current study, PMNL infiltration was eliminated from white matter of group given DMSO. It was observed that TAS level was significantly higher in comparison with SCl group. As noted by Albin et al. (1986) and Chiueh et al. (1994) with studies published in the literature, it is believed that the increase was secondary to free radical scavenging effects of DMSO ${ }^{[30,31]}$ Moreover, increased PON-I activity may be related to effect of DMSO on lipid metabolism.

In the present study, serum and tissue TAS levels and PON-I activity were significantly higher in post-SCl combined treatment group relative to both $\mathrm{SCl}$ and resveratrol monotherapy and quercetin monotherapy groups. In a study conducted by Carvalho et al., ganglioside, MP, and gangliozide+MP combination were administered to rats after $\mathrm{SCl}$ was induced. [32] It was demonstrated that results obtained in combined treatment group were better than MP monotherapy group. Ates et al. demonstrated that neurological improvement was better in combined treatment group relative to MP monotherapy group. ${ }^{[26]}$ In comparison with monotherapy groups and solvent groups, the significantly higher serum and tissue TAS levels and PON activity in combined treatment group as well as serum and tissue levels almost equal to control group may be due to antioxidative and anti-inflammatory potential of both therapeutic agents and the DMSO. In concordance with these findings, the better results obtained in combined treatment group in the post-SCl period relative to monotherapy groups support idea that those two agents and solvent DMSO have synergistic effect.

Elmali et al. demonstrated that resveratrol significantly reduced PMNL infiltration and edema in muscular tissue, changes in length of muscle fibers, and segmented necrosis relative to control group in ischemia-reperfusion injury. ${ }^{[2]}$ As a remarkable common finding, it was observed in the current study that in comparison with $\mathrm{SCl}$ group, PMNL infiltration was reduced in the white matter of post-SCI DMSO and combined treatment groups, in the vessel wall of post$\mathrm{SCl}$ quercetin and combined treatment groups, and in the subarachnoid space of the post-SCl combined treatment group, the reduction of the infiltration tended to completely 
disappear. It was observed that microglia/macrophage/MNL infiltration significantly increased in the white matter of post$\mathrm{SCl}$ quercetin and combined treatment groups in comparison with $\mathrm{SCl}$ group, in the gray matter of post-SCl quercetin group in comparison with the $\mathrm{SCl}$ and post-SCl resveratrol group, and in gray matter of post-SCl combined treatment group in comparison with post-SCl resveratrol group. This effect may derive from anti-inflammatory effects of two drugs and DMSO.

\section{Conclusions}

In summary, our results indicate that resveratrol and quercetin combination alleviated post-SCl oxidative stress. Resveratrol was more effective on primary response, while quercetin was more effective on secondary response, and most effective results were obtained in post-SCl combined treatment group. The 2 compounds may have protected the spinal cord against secondary damage due to possible anti-oxidative effects. We believe that more extensive future studies are warranted to include resveratrol and quercetin in the treatment protocol of SCl.

\section{Conflict of interest: None declared.}

\section{REFERENCES}

1. Profyris C, Cheema SS, Zang D, Azari MF, Boyle K, Petratos S. Degenerative and regenerative mechanisms governing spinal cord injury. Neurobiol Dis 2004;15:415-36. Crossref

2. Yang YB, Piao YJ. Effects of resveratrol on secondary damages after acute spinal cord injury in rats. Acta Pharmacol Sin 2003;24:703-10.

3. LiY, Cao Z, Zhu H. Upregulation of endogenous antioxidants and phase 2 enzymes by the red wine polyphenol, resveratrol in cultured aortic smooth muscle cells leads to cytoprotection against oxidative and electrophilic stress. Pharmacol Res 2006;53:6-15. Crossref

4. Rubiolo JA, López-Alonso H, Martín-Vázquez V, Fol-Rodríguéz NM, Vieytes MR, Botana LM, et al. Resveratrol inhibits proliferation of primary rat hepatocytes in G0/G1 by inhibiting DNA synthesis. Folia Biol (Praha) 2012;58:166-72.

5. Ross JA, Kasum CM. Dietary flavonoids: bioavailability, metabolic effects, and safety. Annu Rev Nutr 2002;22:19-34. Crossref

6. Moutsatsou P. The spectrum of phytoestrogens in nature: our knowledge is expanding. Hormones (Athens) 2007;6:173-93.

7. Chattopadhyay P, Shukla G, Wahi AK. Protective effect of L-arginine against necrosis and apoptosis induced by experimental ischemic and reperfusion in rat liver. Saudi J Gastroenterol 2009;15:156-62. Crossref

8. Rajević N, Matković H, Gregorović G, Kovacević G, Knezović L, Kalafatić M. Behavioral, morphological and histopathological effects of sublethal doses of quercetin on the species Polycelis felina (Dalyell). Folia Biol (Krakow) 2013;61:101-6. Crossref

9. Ciftci O, Vardi N, Ozdemir I. Effects of quercetin and chrysin on 2,3,7,8-tetrachlorodibenzo-p-dioxin induced hepatotoxicity in rats. Environ Toxicol 2013;28:146-54. Crossref

10. Selvakumar K, Bavithra S, Krishnamoorthy G, Venkataraman P, Arunakaran J. Polychlorinated biphenyls-induced oxidative stress on rat hippocampus: a neuroprotective role of quercetin. ScientificWorldJournal 2012;2012:980314. Crossref

11. Kiziltepe U, Turan NN, Han U, Ulus AT, Akar F. Resveratrol, a red wine polyphenol, protects spinal cord from ischemia-reperfusion injury. J Vasc
Surg 2004;40:138-45. Crossref

12. Cemil B, Topuz K, Demircan MN, Kurt G, Tun K, Kutlay M, et al. Curcumin improves early functional results after experimental spinal cord injury. Acta Neurochir (Wien) 2010;152:1583-90. Crossref

13. Ates O, Cayli S, Altinoz E, Gurses I, Yucel N, Sener M, et al. Neuroprotection by resveratrol against traumatic brain injury in rats. Mol Cell Biochem 2007;294:137-44. Crossref

14. Dajas F, Rivera-Megret F, Blasina F, Arredondo F, Abin-Carriquiry JA, Costa G, et al. Neuroprotection by flavonoids. Braz J Med Biol Res 2003;36:1613-20. Crossref

15. Esposito E, Rotilio D, Di Matteo V, Di Giulio C, Cacchio M, Algeri S. A review of specific dietary antioxidants and the effects on biochemical mechanisms related to neurodegenerative processes. Neurobiol Aging 2002;23:719-35. Crossref

16. Zimmermann M, Colciaghi F, Cattabeni F, Di Luca M. Ginkgo biloba extract: from molecular mechanisms to the treatment of Alzhelmer's disease. Cell Mol Biol (Noisy-le-grand) 2002;48:613-23.

17. Genovese T, Mazzon E, Menegazzi M, Di Paola R, Muià C, Crisafulli C, et al. Neuroprotection and enhanced recovery with hypericum perforatum extract after experimental spinal cord injury in mice. Shock 2006;25:608-17. Crossref

18. Schültke E, Kamencic H, Skihar VM, Griebel R, Juurlink B. Quercetin in an animal model of spinal cord compression injury: correlation of treatment duration with recovery of motor function. Spinal Cord 2010;48:112-7. Crossref

19. Schültke E, Kendall E, Kamencic H, Ghong Z, Griebel RW, Juurlink $\mathrm{BH}$. Quercetin promotes functional recovery following acute spinal cord injury. J Neurotrauma 2003;20:583-91. Crossref

20. Costa LG, Vitalone A, Cole TB, Furlong CE. Modulation of paraoxonase (PON1) activity. Biochem Pharmacol 2005;69:541-50. Crossref

21. Mackness B, McElduff P, Mackness MI. The paraoxonase-2-310 polymorphism is associated with the presence of microvascular complications in diabetes mellitus. J Intern Med 2005;258:363-8. Crossref

22. Baum L, Ng HK, Woo KS, Tomlinson B, Rainer TH, Chen X, et al. Paraoxonase 1 gene Q192R polymorphism affects stroke and myocardial infarction risk. Clin Biochem 2006;39:191-5. Crossref

23. Ferretti G, Bacchetti T, Busni D, Rabini RA, Curatola G. Protective effect of paraoxonase activity in high-density lipoproteins against erythrocyte membranes peroxidation: a comparison between healthy subjects and type 1 diabetic patients. J Clin Endocrinol Metab 2004;89:2957-62.

24. Ferretti G, Bacchetti T, Moroni C, Vignini A, Curatola G. Copper-induced oxidative damage on astrocytes: protective effect exerted by human high density lipoproteins. Biochim Biophys Acta 2003;1635:48-54.

25. Rael LT, Bar-Or R, Aumann RM, Slone DS, Mains CW, Bar-Or D. Oxidation-reduction potential and paraoxonase-arylesterase activity in trauma patients. Biochem Biophys Res Commun 2007;361:561-5.

26. Ates O, Cayli S, Altinoz E, Gurses I, Yucel N, Kocak A, et al. Effects of resveratrol and methylprednisolone on biochemical, neurobehavioral and histopathological recovery after experimental spinal cord injury. Acta Pharmacol Sin 2006;27:1317-25. Crossref

27. Elmali N, Esenkaya I, Karadağ N, Taş F, Elmali N. Effects of resveratrol on skeletal muscle in ischemia-reperfusion injury. Ulus Travma Acil Cerrahi Derg 2007;13:274-80.

28. Ray PS, Maulik G, Cordis GA, Bertelli AA, Bertelli A, Das DK. The red wine antioxidant resveratrol protects isolated rat hearts from ischemia reperfusion injury. Free Radic Biol Med 1999;27(1-2):160-9. Crossref

29. Turan NN, Akar F, Budak B, Seren M, Parlar AI, Sürücü S, et al. How DMSO, a widely used solvent, affects spinal cord injury. Ann Vasc Surg 2008;22:98-105. Crossref

30. Chiueh CC, Wu RM, Mohanakumar KP, Sternberger LM, Krishna $\mathrm{G}$, Obata $\mathrm{T}$, et al. In vivo generation of hydroxyl radicals and MPTPinduced dopaminergic toxicity in the basal ganglia. Ann N Y Acad Sci 
1994;738:25-36. Crossref

31. Albin MS, Bunegin L. An experimental study of craniocerebral trauma during ethanol intoxication. Crit Care Med 1986;14:841-6. Crossref
32. Carvalho MO, Barros Filho TE, Tebet MA. Effects of methylprednisolone and ganglioside GM-1 on a spinal lesion: a functional analysis. Clinics (Sao Paulo) 2008;63:375-80. Crossref

\title{
DENEYSEL ÇALIŞMA - ÖZET
}

\section{Deneysel spinal kord travması sonrası resveratrol ve kuersetin' in etkinliğinin araştırılması \\ Dr. Ulvi Çiftçi,, Dr. Emre Delen, ${ }^{2}$ Dr. Murat Vural, ${ }^{3}$ Dr. Onur Uysal, ${ }^{4}$ Dr. Didem Turgut Coşan, ${ }^{5}$ \\ Dr. Canan Baydemir, ${ }^{6}$ Dr. Fulya Doğaner ${ }^{5}$}

\author{
${ }^{1}$ Bakırköy Dr. Sadi Konuk Eğitim ve Araştırma Hastanesi, Nöroşirürji Kliniği, İstanbul \\ ${ }^{2}$ Trakya Üniversitesi Tıp Fakültesi, Nöroşirürji Anabilim Dalı, Edirne \\ ${ }^{3}$ Eskişehir Osmangazi Üniversitesi Tıp Fakültesi, Nöroşirürji Anabilim Dalı, Eskişehir \\ ${ }^{4}$ Eskişehir Osmangazi Üniversitesi Tıp Fakültesi, Histoloji Anabilimdalı, Eskişehir \\ ${ }^{5}$ Eskişehir Osmangazi Üniversitesi Tıp Fakültesi, Medikal Biyoloji Anabilim Dalı, Eskişehir \\ ${ }^{6}$ Kocaeli Üniversitesi Tıp Fakültesi, Biyoistatistik Anabilim Dalı, Kocaeli
}

AMAÇ: Bu çalışmada, doğal antioksidanlardan olan resveratrol ve kuersetin'in, deneysel spinal kord travması oluşturulmuş sıçanlarda, oksidatif stres ve sekonder doku hasarı üzerine olan etkilerini araştırmak amaçlandı.

GEREÇ VE YÖNTEM: Bu deneysel çalışmada, 42 adet Sprague-Dawley cinsi erkek sıçan kullanıldı. Spinal kord hasarı klip kompresyon metodu kullanılarak T4-T5 seviyesinden yapıldı. Çalışma kontrol, travma, travma+çözücü, travma+resveratol, travma+kuersetin ve travma+kombine (resveratrol ve kuersetin) olmak üzere 6 grup üzerinden yürütüldü. İşlemden 48 saat sonra tüm sıçanlar sakrafiye edildi. Resveratrol ve kuersetin'in serum ve dokuda total antioksidan kapasite düzeyi ve paraoksonaz enzim aktivitesine ve histopatolojik bulgulara olan etkisi araştııllı.

BULGULAR: Sonuç olarak resveratrol, kuersetin ve kombine tedavi verilen gruplarda TAOK düzeyi ve PON aktivitesi değerlerinde travma grubuna göre anlamlı bir artma saptandı. Resveratrol ve kuersetin grupları arasında TAOK düzeyi ve PON aktivitesi açısından anlamlı bir farklıık yoktu. Çözücü grubunda TAOK düzeyi ile PON aktivitesi travma grubuna göre anlamlı derecede yüksekti. Histopatolojik incelemede ise sadece çözücü, resveratrol, kuersetin ve kombine tedavi gruplarında PMNL infiltrasyonunun azaldığı görüldü.

TARTIŞMA: Çalışmamızdaki biyokimyasal ve histolojik değerlendirmede resveratrol ve kuersetin uygulamasının spinal kord travmasında görülen ikincil hasardan, spinal kordu korumak için kullanılabileceği sonucuna varılmıştır.

Anahtar sözcükler: Antioksidan; deneysel spinal kord hasarı; kuersetin; resveratrol.

Ulus Travma Acil Cerrahi Derg 2016;22(5):423-43। doi: 10.5505/tjtes.2016.44575 